\title{
REPRODUCTIVE PATTERN, SIZE AT FIRST MATURITY AND STOCK-RECRUITMENT RELATIONSHIPS OF THE ARGENTINE STILETTO SHRIMP (ARTEMESIA LONGINARIS, DECAPODA: PENAEIDAE) IN SOUTHERN BRAZIL
}

\author{
LUIZ FELIPE DUMONT; IRECE FARINA MACHADO \& FERNANDO D'INCAO \\ Institute of Oceanography; Universidade Federal do Rio Grande - Caixa postal: 474 - Rio Grande - RS - Brazil. CEP: $96201-900$ - \\ felipe_dumont@hotmail.com
}

\section{Padrão reprodutivo, tamanho de primeira maturação e relações estoque/recrutamento do camarão-barba-ruça Artemesia longinaris no sul do Brasil.}

Artemesia longinaris tem sido recentemente explorado pela pesca artesanal e industrial no Sul do Brasil. Para investigar a biologia reprodutiva desta espécie no Sul do Brasil, amostras mensais, entre as profundidades de 5 e 20 metros, foram analisadas entre Fevereiro/2002 e Janeiro/2003. Relações entre estoque desovante e recrutamento (RER) foram estimadas, assim como um modelo preliminar para previsão de biomassa. O esforço reprodutivo está concentrado na primavera, entretanto, foi observado um recrutamento contínuo ao longo do ano. A reprodução durante o outono é mais variável e susceptível a chuvas intensas e consequentemente menores salinidades observadas na área de estudo. Uma migração reprodutiva, para profundidades em torno dos 15 metros, foi observada e o recrutamento inicia aproximadamente 1 mês após a desova. O tamanho médio de primeira maturação foi estimado em 16,76 $\mathrm{mm}$ e é atingido em aproximadamente 4 meses. Um ajuste significativo dos dados aos modelos de estoque-recrutamento (RER) foi obtido sob condições ambientais adversas, sugerindo que a redução do estoque desovante possa resultar em uma sobrepesca de recrutamento. Um modelo preliminar de previsão de abundância foi desenvolvido e o fator de maior influência no recrutamento foi a salinidade durante a principal temporada de desova (primavera). Já para os anos de condições ambientais desfavoráveis, o principal fator foi a biomassa do estoque desovante, enquanto que em anos de condições favoráveis a salinidade foi o principal fator.

PALAVRAS CHAVE: Avaliação de estoque, peneídeos, biologia pesqueira, reprodução, manejo pesqueiro.

\section{ABSTRACT}

Artemesia longinaris has been recently exploited by commercial and artisanal fisheries in Southern Brazil. To investigate the reproductive biology of this species, monthly samples were analyzed between February/2002 and January/2003, in depths between 5 and 20 meters in surrounding area of the Barra do Rio Grande. Stock-recruitment relationships (SRR) were estimated, as well as a preliminary predictive model for recruit biomass. Reproductive effort is concentrated in spring; however, recruitment was observed year round. Reproduction in autumn is more variable, and susceptible to intense rainfall and consequent low salinity observed in the studied area. A reproductive migration to depths farther than 15 meters was observed, and recruitment in shallower waters starts approximately one month after hatching. Mean length at first maturity was estimated in $16.76 \mathrm{~mm}$ and is achieved in approximately 4 months. Significant fit of stock-recruitment relationships (SRR) was observed for three models tested under adverse environmental conditions, suggesting that the reduction of spawning biomass combined with unfavorable environmental conditions may lead to recruitment overfishing. A preliminary predictive model was developed and the main factor influencing recruitment of the species is salinity in spawning season. The main factor influencing recruitment success under adverse environmental conditions is the biomass of spawning stock, while under favorable conditions salinity in spawning season plays a significant role.

KEYWORDS: stock assessment, penaeid shrimps, fishery biology, reproduction, fishery management

\section{INTRODUCTION}

Artemesia longinaris Bate, 1888 is a penaeid shrimp commercially exploited along its entire distribution area, from Rio de Janeiro $\left(21^{\circ} 37 \mathrm{~S}\right)$, Brazil to Puerto Rawson $\left(43^{0} 00 S\right.$ ), Argentina. The stiletto shrimp is usually used as food for human consumption as well as for bait in amateur fishery. This species is caught along with Pleoticus muelleri, the larger red shrimp, which is also a valuable fishery resource in Southern Brazil and Argentina (Boschi 1969; D'Incao et al. 2002).

Commercial landing in Brazilian coast dates back from 1978, however, landing statistics were only available after 1982, showing remarkable increases in recent decades (Univali 2011). The growing interest and increasing fishing effort over $A$. longinaris, especially after the collapse of pink shrimp fishery
(D'Incao et al. 2002), raise the need for new investigations about its population dynamics.

Although penaeid stocks throughout the tropics and subtropics support highly profitable fisheries (FAO 2007), little is known about the population dynamics of several species (Cha et al. 2002). Regarding population parameters, one of the most important is the size or age at first maturity, which is widely used as a biological reference point for managing exploited stocks (Gulland \& Rothschild 1981, Cha et al. 2002; López-Martinez et al. 2005, Frisch 2007) since preservation of individuals smaller than mean size at first maturity increases the chance of success of the next offspring (Garcia \& Le Reste 1981, King 1997).

Few previous investigations concerned on the reproduction and ovary maturation of $A$. longinaris 
from Southern Brazil (Nascimento 1981, Dumont \& D'Incao 2004, Castillo et al. 2007). Using variation of size at first maturity, a hypothesis of two different populations was stated for this species (Nascimento 1981). However, the trait used to define morphological maturity was the presence of a spermatophore, which is presently known to be invalid as an indicator of ovarian maturity for this species, since females can carry spermatophores without being fully mature (Scelzo 1991). Dumont \& D'Incao (2004) established a chromatic scale, based on ovarian microscopic traits, to identify stages of gonadal development of $A$. longinaris more accurately, providing a routine method to classify the ovaries. Recently, Castillo et al. (2007) investigated trends in size at first maturity in populations inhabiting distribution limits of the species.

Furthermore, investigations on penaeid shrimps biology suggest conspicuous trends in reproductive dynamics for this group, highly dependent on environmental conditions (Staples et al. 1985, Vance et al. 1998, Crocos et al. 2001). Recruitment of juveniles and larval abundance of $A$. longinaris has been previously assessed and marked oscillations in time and intensity of reproduction were reported, even though the main breeding season in Southern Brazil is accepted as taking place in spring (Nascimento 1981, Ruffino \& Castello 1992, Calazans 2002). Previous studies suggest that main reproductive season in Argentina takes place in summer and that endogenous and environmental factors may affect reproduction of this species in that area (Boschi 1969, Christiansen \& Scelzo 1971, Scelzo 1991, Petriella \& Bridi 1992). In Southeastern Brazil reproduction was

\section{MATERIAL AND METHODS}

\section{Study area}

Sampling took place in surrounding area of the Barra de Rio Grande, which links the estuary to marine coastal waters through a four kilometers channel (Figure 1). This area is strongly influenced by freshwater discharge from Patos Lagoon Estuary (Ciotti et al. 1995) and discharge values of $30,300 \mathrm{~m}^{3} \mathrm{~s}^{-1}$ have been reported (Garcia 1996). The estuary is located at reported to take place in summer, associated with cold water upwelling (Costa et al. 2005).

Prediction of recruitment is also of special interest for penaeid fisheries management (Pauly 1992). Forecasting recruit abundances in penaeid populations has been considered a hard task due to their high fecundity and susceptibility to environmental changes, such as those caused by rainfall and wind stress (Garcia 1981; Gulland \& Rothschild 1981, Crocos et al. 2001). Despite that, stock-recruitment relationships (SRR) have been applied to estimate recruitment of penaeid with considerable level of success (Garcia 1981, Kirkwood 1981, Pauly 1992).

There is evidence that level of recruitment is at least partly governed by environmental conditions and interactions between spawning stock and recruitment, and environmental conditions must be investigated to properly manage and predict future abundances (Pauly 1992). There are, therefore, many aspects of interaction between shrimp biology and environment that must be carefully considered, especially under low spawning biomass levels (Garcia 1981, Kirkwood 1981, Gulland \& Rothschild 1981, Dall et al. 1990, Pauly 1992).

The aim of this paper is to investigate the mean size at first maturity, reproductive dynamics, stockrecruitment relationships as well as to develop a preliminary model to predict the abundance of $A$. longinaris recruits in the commercial fishery of extreme Southern Brazil.

coastal plain of Rio Grande do Sul State, Brazil $\left(32^{\circ} \mathrm{S}\right.$, $49^{\prime} \mathrm{W}$ ) and it is the largest choked lagoon in the world, accounting for an area of $10,360 \mathrm{~km}^{2}$. Drainage basin covers $201,626 \mathrm{~km}^{2}$ (Asmus 1996) and rainfall as well as wind stress regulate the water movements in study area (Garcia 1996, Piola et al. 2004, 2005). Seasonal freshwater discharge presents great variability $(30,300$ - $47 \mathrm{~m}^{3} \mathrm{~s}^{-1}$ ) and during El Niño Southern Oscillation (ENSO) events runoff is usually higher than mean values estimated $\left(3,000 \mathrm{~m}^{3} \mathrm{~s}^{-1}\right)$ (Garcia 1996). 


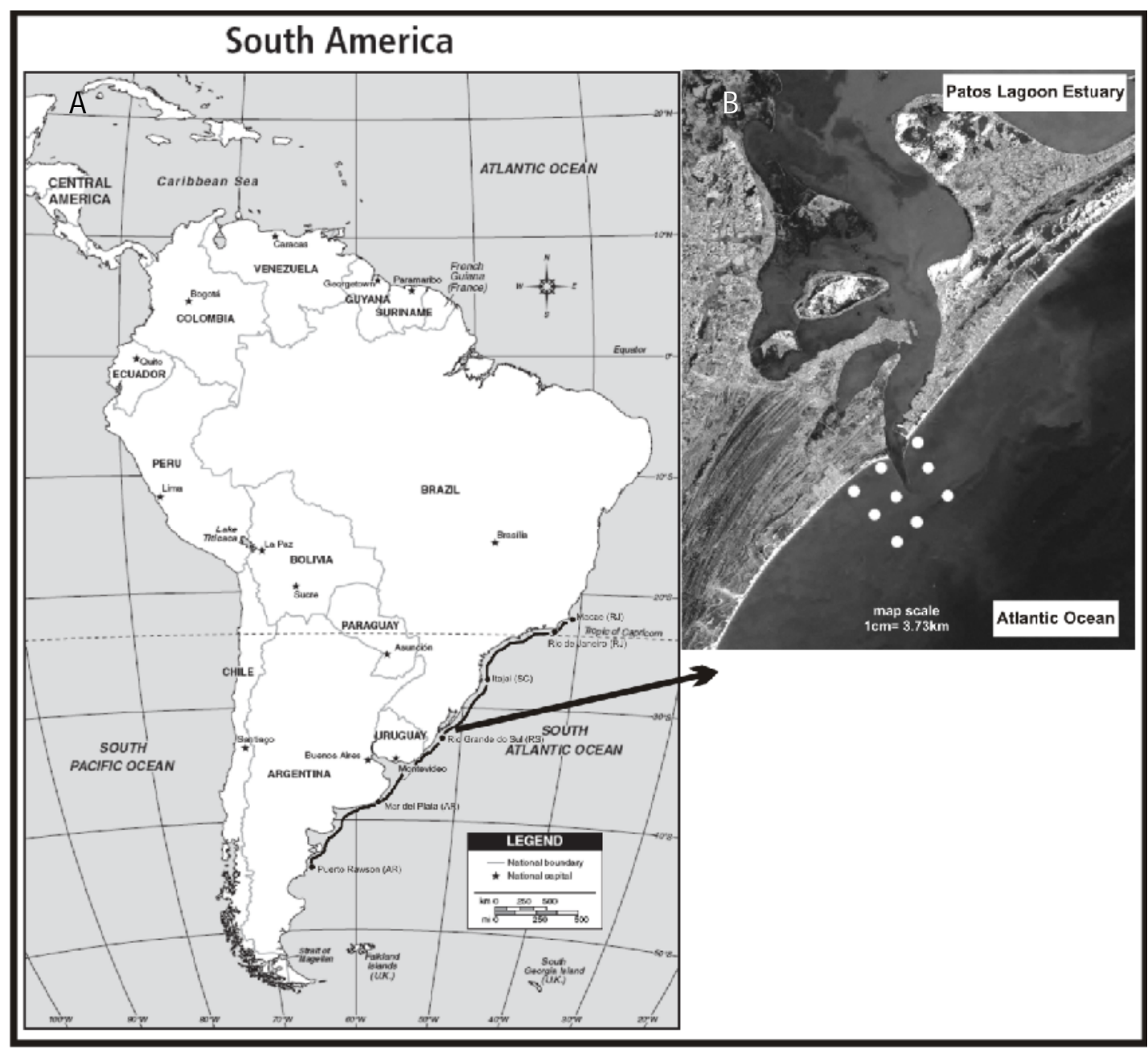

FIGURE 1 - A- Southwestern Atlantic Ocean and distribution of $A$. longinaris in coastal waters (black line). B- Closer view of Southern Brazilian coast, highlighting the surrounding area of Patos Lagoon Estuary and nine sampling stations (white dots) positioned at depths varying from 5 to 20 meters.

\section{Data sources}

Standardized data used in this paper were obtained during oceanographic cruises (L.Oc. Larus) from 1982 to 2003 , in depths varying from 5 to 20 meters. To investigate reproductive pattern only data obtained during 2002/2003 were analyzed, since during previous research cruises, ovary classification had not been performed. To estimate stockrecruitment relationship (SRR), data between 1982 and 2003 were selected based on availability of information from spawning biomass and subsequent recruitment and only nine, out of twenty one years,

\section{Reproductive dynamics and size at first maturity}

To establish relative abundance index (CPUE) the catch unit adopted was number of individuals and the effort unit used was five minutes trawling. Mean relative abundances were statistically compared by were used. Discard of twelve years was due to gaps in collections during spawning or recruitment periods. Spawning season was considered as spring (October, November, December) and recruitment as summer (January, February, March). It is important to stress that the main reproductive event takes place in spring and commercial trawling for $A$. longinaris concentrates maximum fishing effort during summer (Univali 2011). Therefore, commercial fishery depends on recruitment originated from cohorts hatched during previous spring spawning season.

One-Way ANOVA and subsequent post-hoc Tukey test (3 or more means compared) or $t$ test (2 means compared), with confidence level of $95 \%$. Assumptions of normality (Kolmogorov-Smirnov) and 
homogeneity of variances (Levene) were tested prior to perform ANOVA.

Carapace length $(C L)$ was used to describe the size structure of population, as measured from postorbital angle to the end of mid-dorsal carapace. Sizeclass interval used was $0.5 \mathrm{~mm}(\mathrm{CL})$. Ovary development was classified based on color and shape traits, previously established by using histological sections. Three ovarian development stages were adopted (I-immature, II-developing, III-ripe) (Dumont \& D'Incao 2004).

Recruitment patterns were obtained using the ELEFAN II routine (Pauly 1987), included in FISAT program (Gayanilo et al. 1995). Growth parameters used to estimate peaks of recruitment were obtained from von Bertalanffy growth model (VBGM). Monthly relative frequency of ripe (stage III) females was compared to the recruitment pattern generated by ELEFAN II to validate the pattern obtained. Modal groups of females were tentatively linked to visualize modal progression along the sampling period. To estimate growth parameters all the chosen cohorts

\section{Stock-recruitment relationships (SRR) and multiple regression analysis}

Standardized data obtained from oceanographic cruises (L.Oc. Larus) were used to estimate spawning (females larger than LM caught during spring) and recruitment (females smaller than LM caught during summer) abundance index ( $g / 30$ minutes of trawling).

According to Gulland \& Rothschild (1981) a single spawning-recruitment (SRR) curve cannot entirely describe the changes in stock biomass of an exploited shrimp population. Besides spawning biomass, environmental factors play an important role in recruitment success and therefore must be considered in stock assessment (Garcia 1981, Kirkwood 1981, Gulland \& Rothschild 1981, Dall et al. 1990). Thus, two different SRR were visually established and their respective environmental parameters investigated, in such a way that one curve was estimated for favorable environmental conditions (1988, 1989, 2000, 2002) and another for adverse years, where the same spawning stock resulted in a smaller recruitment biomass (1982, 1983, 1984, 1996, 2001). were fitted to von Bertalanffy growth model (VBGM) (1938) by an automated least squares fitting procedure. The von Bertalanffy equation is given by:

$$
C L t=C L_{\infty}\left[1-e^{\left(-k\left(t-t_{0}\right)\right)}\right],
$$

where $C L t$ is length at the time $t, C L_{\infty}$ is asymptotic carapace length, $k$ the coefficient of growth and to the theoretical age at zero length. Longevity $\left(t_{\max }\right)$ was estimated by inverted von Bertalanffy (1938) equation, considering maximum longevity $\left(t_{\max }\right)$ as reached at $99 \%$ of the asymptotic length (D'Incao \& Fonseca 2000).

Mean size at first maturity (LM) was considered as the size class interval ( $1 \mathrm{~mm}$ interval) in which frequency of ripe females is $50 \%$ (King 1997). Frequency of ripe females was fitted to the logistic model by an automated least square procedure, in such a way that:

$$
\left.\left.P=1 /\left[1+\exp ^{(-r(C L},-L M\right)\right)\right]
$$

where $P$ is the percentage of ripe females in a given length class, $r$ is the logistic curve slope, $C L_{1}$ is the upper limit of carapace size interval and $L M$ is the mean length at first maturity.

Stock-recruitment relationships (SRR) were obtained by using three different models. The Beverton \& Holt (1957 apud King 1997) model assumes that recruitment achieves an asymptotic value of biomass at high spawning stock abundances and the equation that describes it is given by:

$$
R=S /(a+b S)
$$

where $R$ is the abundance of recruits in the next year, $S$ is the spawning biomass and $a$ and $b$ are the parameters of the model.

The Ricker (1975 apud King 1997) equation describes a stock-recruitment relationship where recruitment achieves a maximum and decreases afterwards at high spawning biomass levels. The equation is given by:

$$
R=a S \exp (-b S)
$$

where $R$ is the abundance of recruits in the next year, $S$ is the spawning biomass and $a$ and $b$ are the parameters of the model.

The last model fitted was created by Shepherd (1982 apud King 1997).

$$
R=a S /\left[1+(S / K)^{b}\right]
$$

The parameters $R$ and $S$ have the same meaning as in other equations. The parameter $a$ is the 
initial slope at the origin and reflects the potential stock-recruitment relationship without the densitydependent effects. The parameter $K$ represents the threshold spawning biomass above which densitydependent effects dominate density-independent effects. Specifically, $K$ is the stock size at which recruitment is reduced to one half the level it would have been under density-independent process only (King 1997). Spawning stock and recruitment abundances were fitted to SRR models by an automated least square procedure. Mean salinity and rainfall during spring were grouped according to good and bad recruitment years (visually determined according to SRR) and then compared by a $t$ test at $5 \%$ significance level.

Multiple regression analysis was performed to

\section{RESULTS}

\section{Environmental data}

Rainfall data collected for the city of Rio Grande was chosen due to higher correlation with salinity in surrounding area of Patos Lagoon $(r=0.73, b=0.049$, $\mathrm{p}<0.10$ ). Conversely, polled rainfall data from all drainage basin did not show a close relationship with salinity. Lack of correlation may be due to complex interactions between rainfall and wind stress (Garcia 1996), resulting in a larger gap between rainfall and freshwater runoff. elucidate main environmental and biological factors affecting the reproductive success of $A$. longinaris in surrounding area of Patos Lagoon estuary. Predictors used were: total rainfall in spawning (RSS) (spring) and recruitment seasons (RRC) (summer), salinity in spawning season (SALS) (spring), salinity in recruitment (SALR) and spawning biomass (SS). Recruitment abundance in subsequent summer $(\mathrm{RC})$ was considered as the dependent variable. A forward stepwise method was chosen, in such a way that most important predictors $(p<0.1)$ were progressively included in regression equation. Salinity data was measured with a termosalinometer after each fishing station. Daily rainfall $\left(\mathrm{mm}^{3}\right)$ data was obtained from Estação Agrometeorológica da Universidade Federal de Pelotas, and seasonally grouped as previously mentioned.

Mean annual rainfall, between 1913 and 2002, in the city of Rio Grande was $1215 \mathrm{~mm}^{3}$. Total rainfall recorded in 2002 was the highest since 1915, reaching the value of $1915 \mathrm{~mm}^{3}$. Values recorded in 2002 were consistently above typical values for the area, except in July, when slightly lower rainfall was observed. Four main peaks of rainfall were observed in January $\left(241.7 \mathrm{~mm}^{3}\right)$, March $\left(224.2 \mathrm{~mm}^{3}\right)$, October $\left(195.8 \mathrm{~mm}^{3}\right)$ and December $\left(272.7 \mathrm{~mm}^{3}\right)$ (Figure 2).

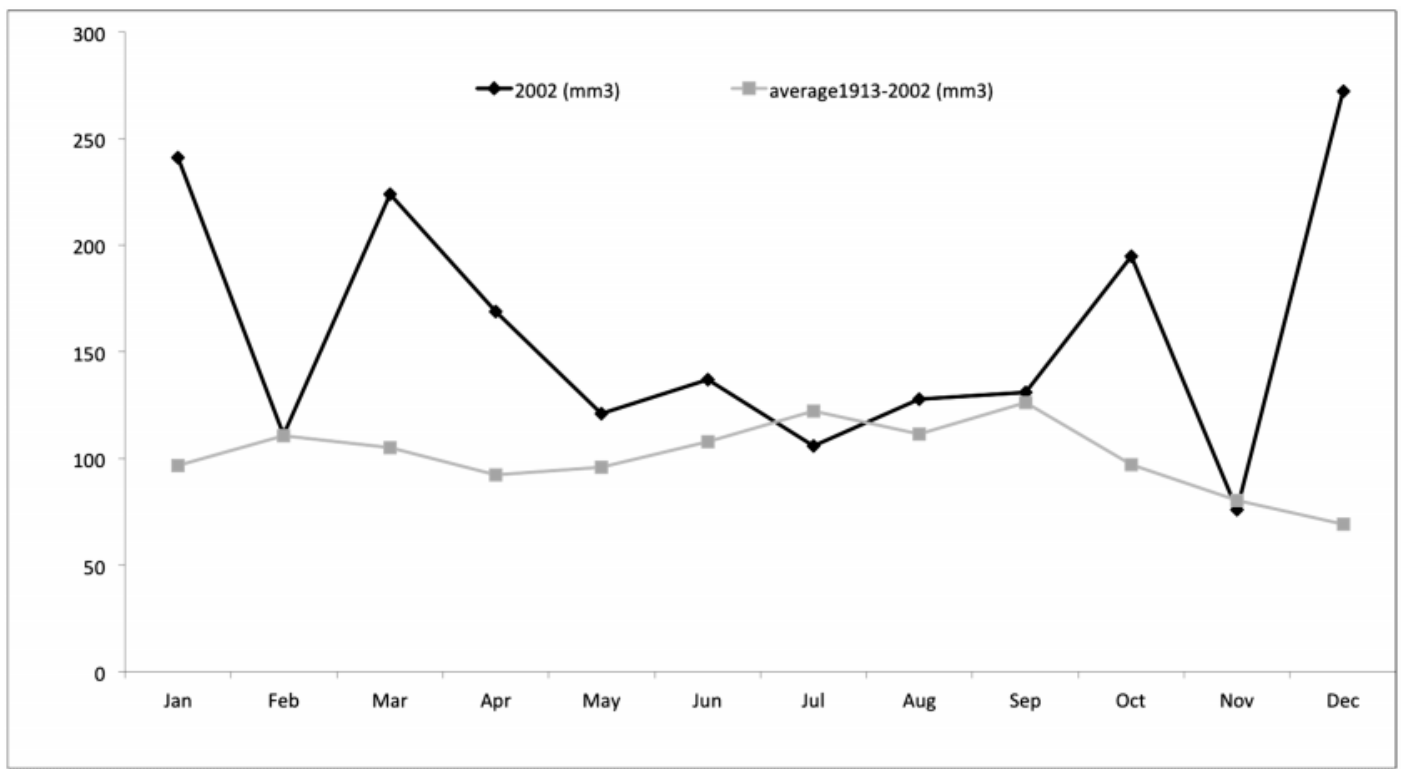

FIGURE 2 - Trends in rainfall $\left(\mathrm{mm}^{3}\right.$ ) observed during 2002 for the city of Rio Grande (Southern Brazil), compared to average values from 1913 to 2002 . 
Higher values of salinity were observed in summer (February= $30.2 \pm 0.39$ ), despite of a striking reduction of values in March (24.4 \pm 1.8$)$, as a consequence of intense rainfall during this month. Salinity tended to decrease towards winter when lowest values were recorded (September $=19.07 \pm 5.37)$. After the winter, salinity increased again towards December (23.1 \pm 5.83$)$, when another reduction, associated to high rainfall, was noticed (Figures 2, 3).

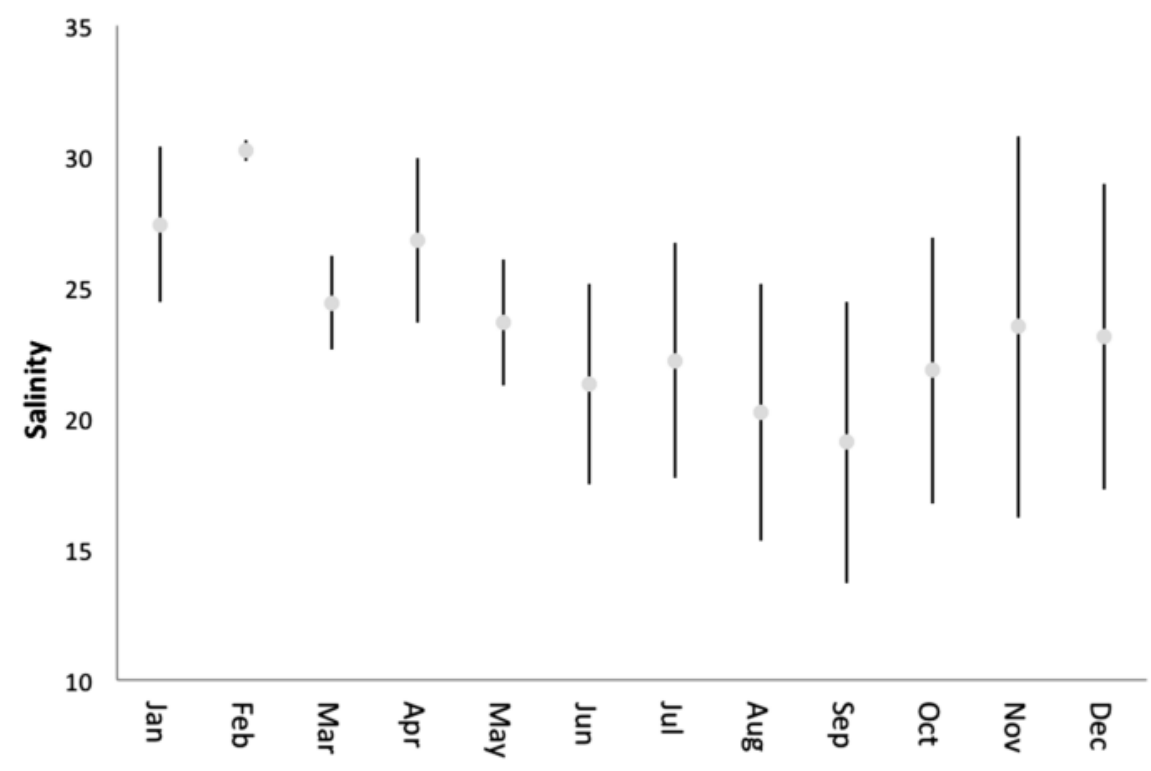

FIGURE 3 - Trends in mean salinity in surrounding area of Barra do Rio Grande, Southern Brazil. Black dots represent mean values and vertical bars represent the range in sampled values.

As expected, temperatures were higher in summer (January $=25.64 \pm 0.78$ ) and lower in winter (August $=13.7 \pm 0.6)$. From September $(15.75 \pm 0.5)$ onwards, temperatures increased and stabilized between November $(21.4 \pm 0.3)$ and December

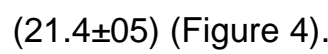

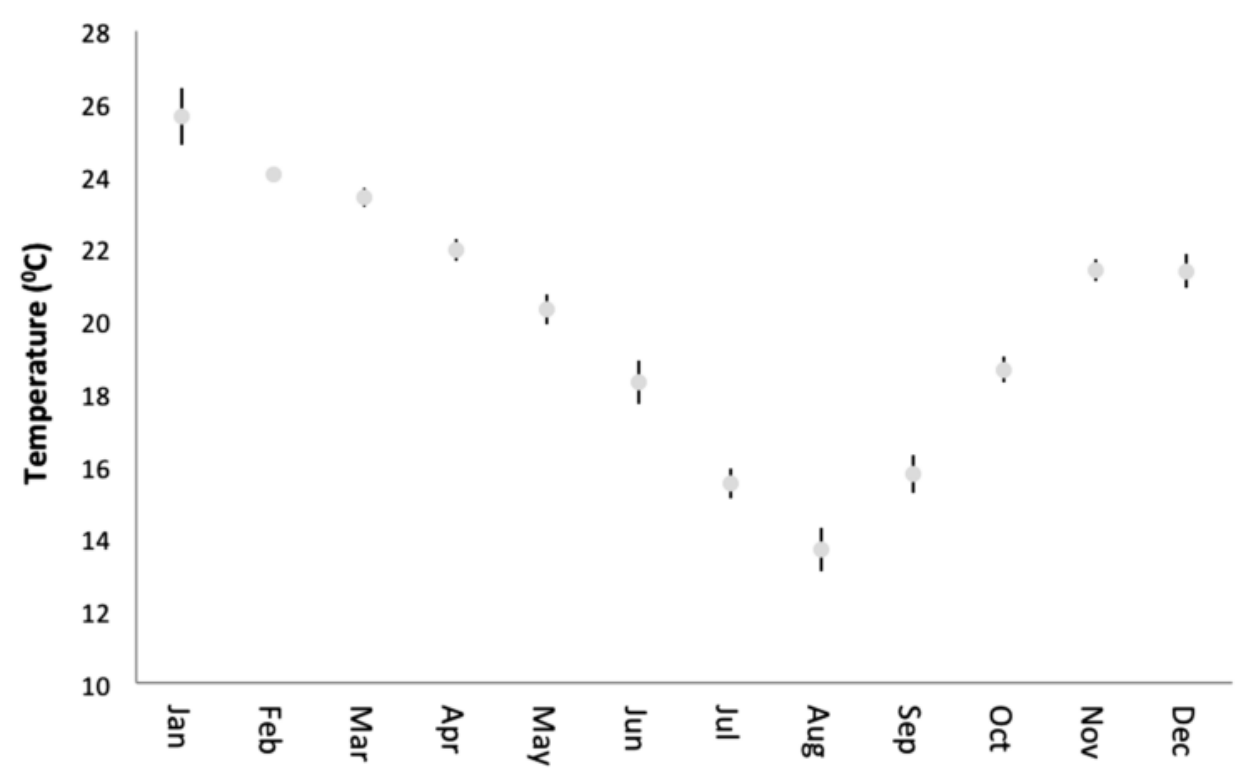

FIGURE 4 - Trends in mean water temperature $\left({ }^{\circ} \mathrm{C}\right)$ in surrounding area of Barra do Rio Grande, southern Brazil. Black dots represent mean values and vertical bars represent the range in sampled values. 
Seasonal reproductive dynamics and size at first maturity

A total of 2623 females was analyzed between January/2002 and January/2003 for reproductive pattern and size at first maturity estimates. Ripe, vitellogenic and adult females were recorded year round, but mainly from July to October. Conversely, very low frequencies of ripe females were recorded in May and January/2002 (Figure 5).

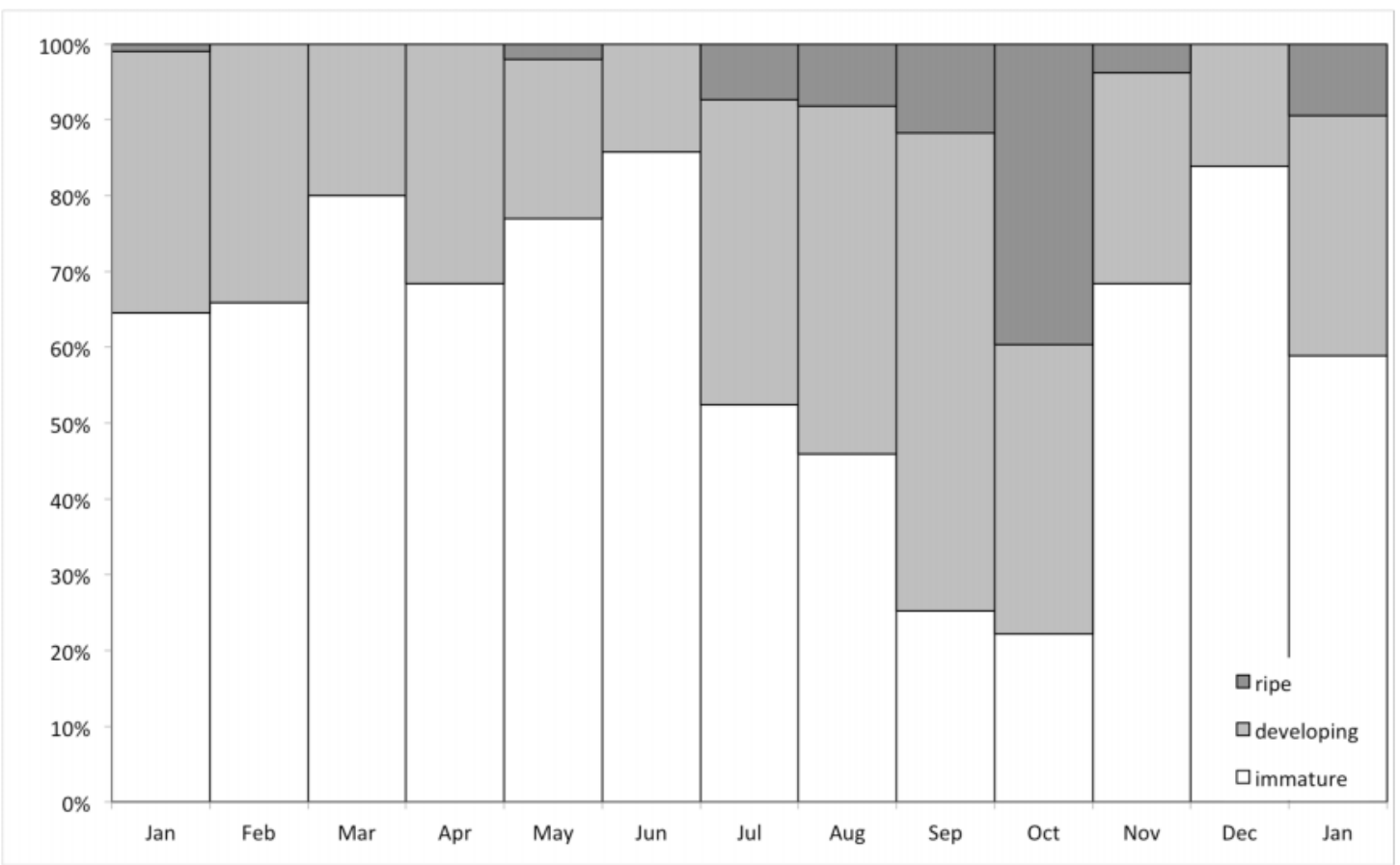

FIGURE 5 - Frequency of immature, developing and ripe females of $A$. longinaris between January 2002 and January 2003.

Three peaks of adult females and proportion of ripe ovaries were observed along the year (Figures 5, 6 ). The highest density of adult females was recorded in October (38.86\%) (Figure 5). In May, another high mean relative abundance of adult females was recorded (12 shrimps/min) (Figure 6). However, a very low proportion of ripe ovaries during this month was observed $(<5 \%)$ (Figure 5$)$. In January, the smallest abundance of $A$. longinaris females was observed (1 shrimp/min), also with a low percentage of mature ovaries $(<5 \%)$ (Figures 5,6$)$. 


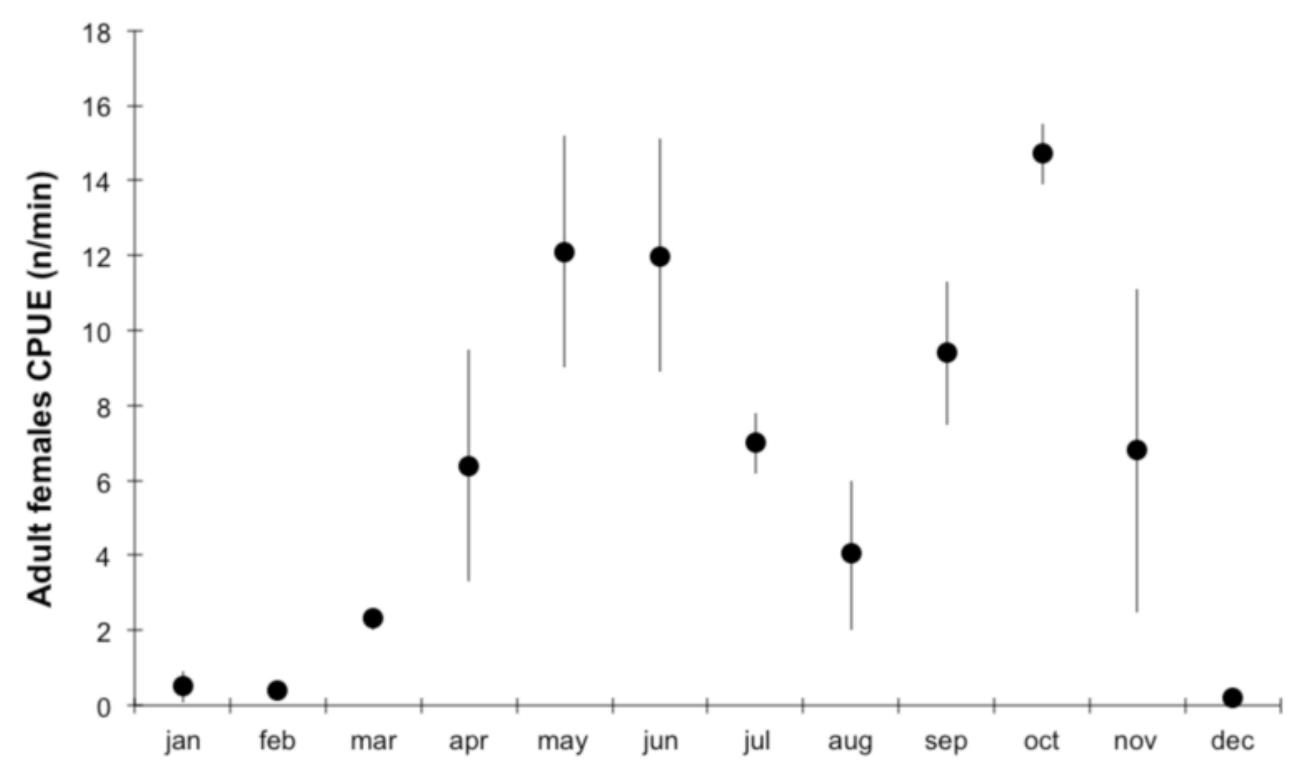

FIGURE 6 - Monthly relative abundance (CPUE in numbers/minute) of $A$. longinaris adult females in Southern Brazil. Vertical bars represent standard deviation of means.

Trends in relative abundance of recruits coincide with pattern estimated by ELEFAN II routine, which resulted in three peaks along the year (Figure 6). Recruitment peaks presented a one-month delay after maximum values of adult females and proportion of ripe females (Figures 5, 6, 7, 8). Main recruitment event takes place in November, as indicated by high percentage (Figure 7) and relative abundance (Figure 8) of individuals smaller than LM. The other two recruitment events are less important in magnitude and took place in February and June (Figures 7, 8).

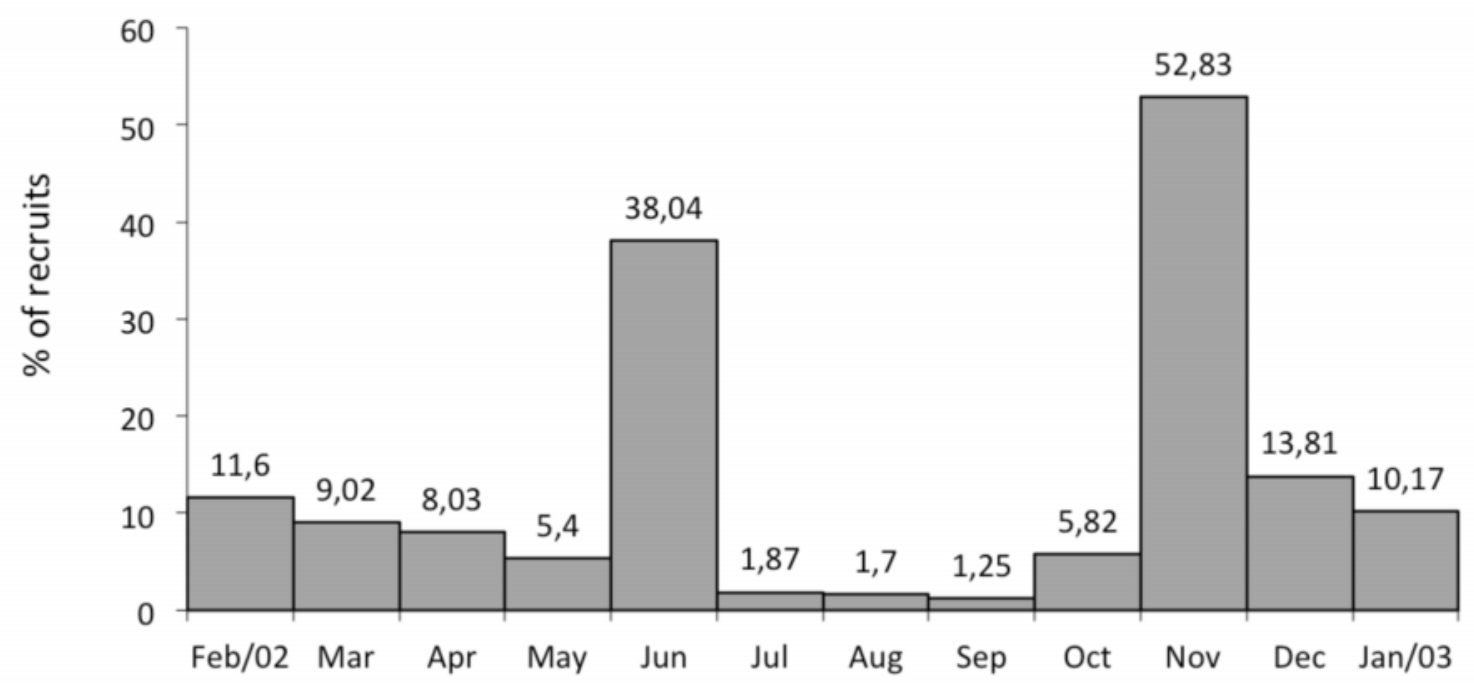

FIGURE 7 - Monthly recruitment pattern estimated by ELEFAN II routine for A. longinaris females in Southern Brazil. Values above grey bars indicate frequency of recruits in samples. 


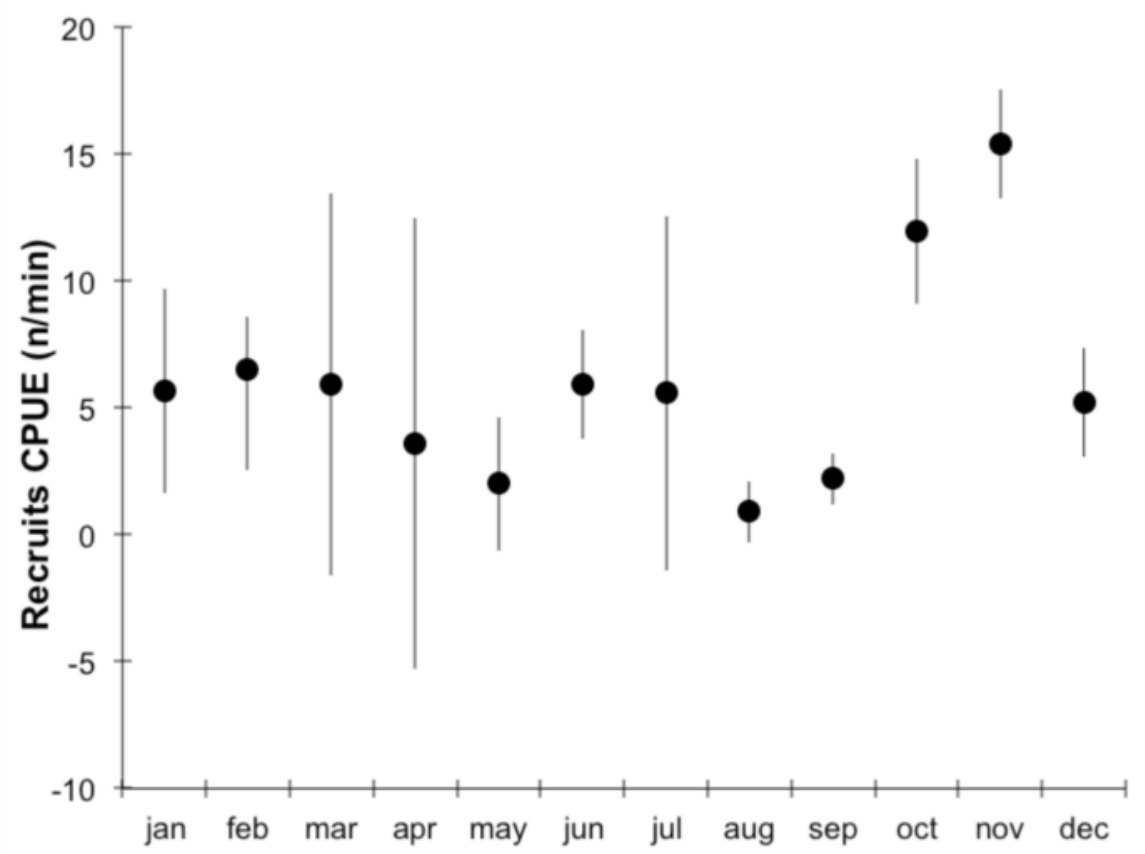

FIGURE 8 - Monthly relative abundance (CPUE in numbers/minute) of $A$. longinaris recruits (females) in Southern Brazil. Vertical bars represent standard deviation of means.

Smallest ripe female measured was $13.3 \mathrm{~mm}$ and the largest $30.49 \mathrm{~mm}$. Estimated mean length at first maturity (LM) was $16.76 \mathrm{~mm}$ (Figure 9, Table I) and based on length-age table, obtained from VBGM, the LM estimated corresponded to the age of approximately 4 months. The length at which $100 \%$ of females were mature was $25.0 \mathrm{~mm}$, corresponding to the age of 8 months (Figure 9).

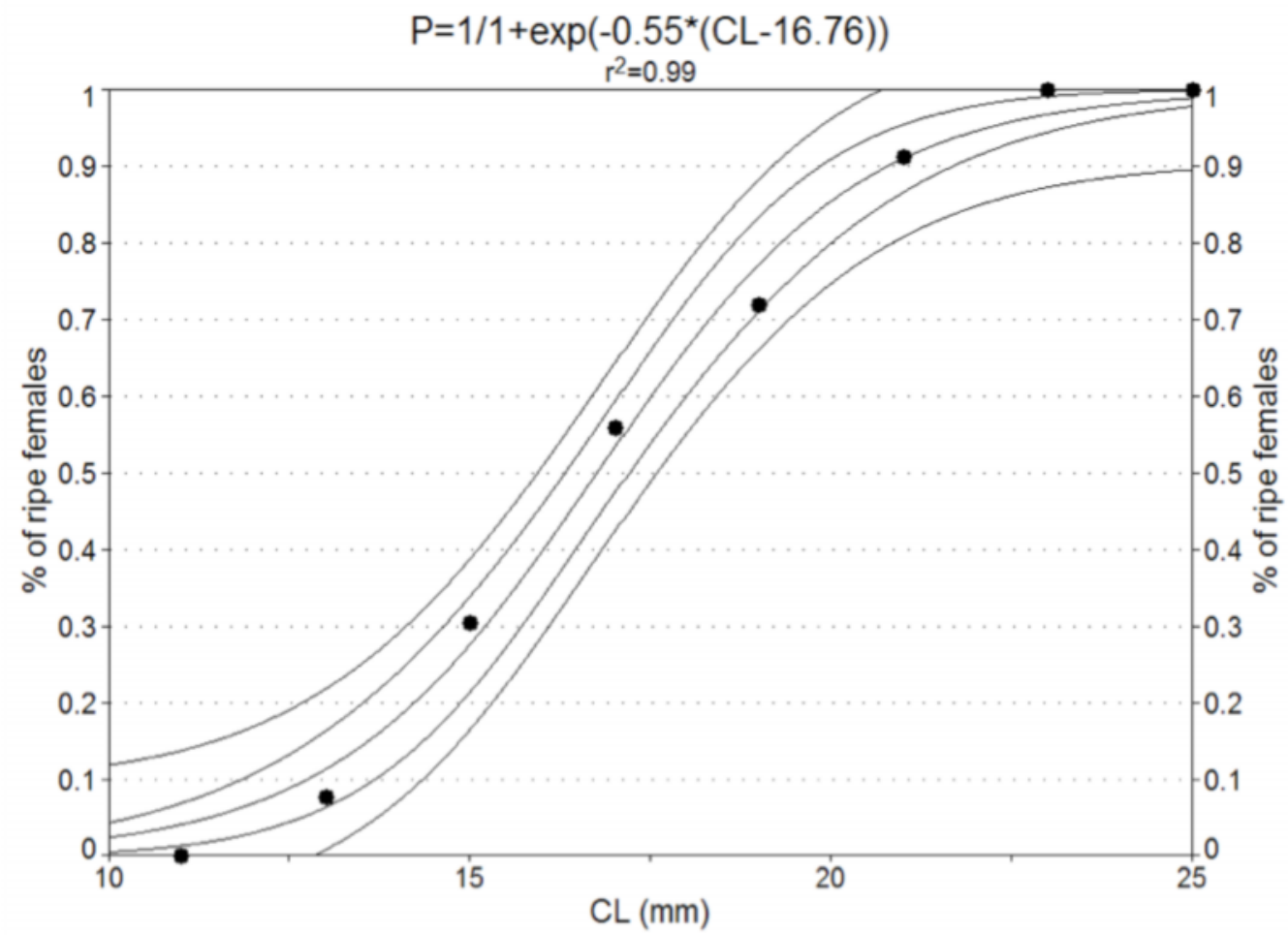

FIGURE 9 - Logistic curve of ovary maturation for estimated A. longinaris. Carapace length (CL $\mathrm{mm})$ that corresponds to frequency of $50 \%$ is $16.76 \mathrm{~mm}$. Length at which $100 \%$ of females presented ripe ovaries is $25 \mathrm{~mm}$. External lines represent the confidence interval of estimate (95\%) and internal bands the prediction interval (95\%). 
TABLE I - Summary of estimates obtained from least square procedure that fitted the frequency of $A$. longinaris ripe females to a logistic model, containing slope ( $r$ ), length at first maturity (LM), t-values, confidence limits (CI95\%) and p-values.

\begin{tabular}{ccccc}
\hline Parameter & value & \multicolumn{2}{c}{$\mathrm{Cl}(95 \%)$} & $\mathrm{p}$ \\
\hline$r$ & 0.55 & 0.43 & 0.66 & 0.000 \\
$\mathrm{LM}$ & 16.76 & 16.33 & 17.19 & 0.000 \\
\hline
\end{tabular}

\section{Size frequency and VBGM analysis}

Carapace lengths ranged from $3.1 \mathrm{~mm}$ to $30.49 \mathrm{~mm}$ and larger females were observed from winter to spring (July, August, September and
October). During March $(10.35 \mathrm{~mm})$, May $(11.70 \mathrm{~mm})$, November $(10.72 \mathrm{~mm})$ and December $(10.81 \mathrm{~mm})$ the lowest mean $C L$ values were recorded (Figure 10).
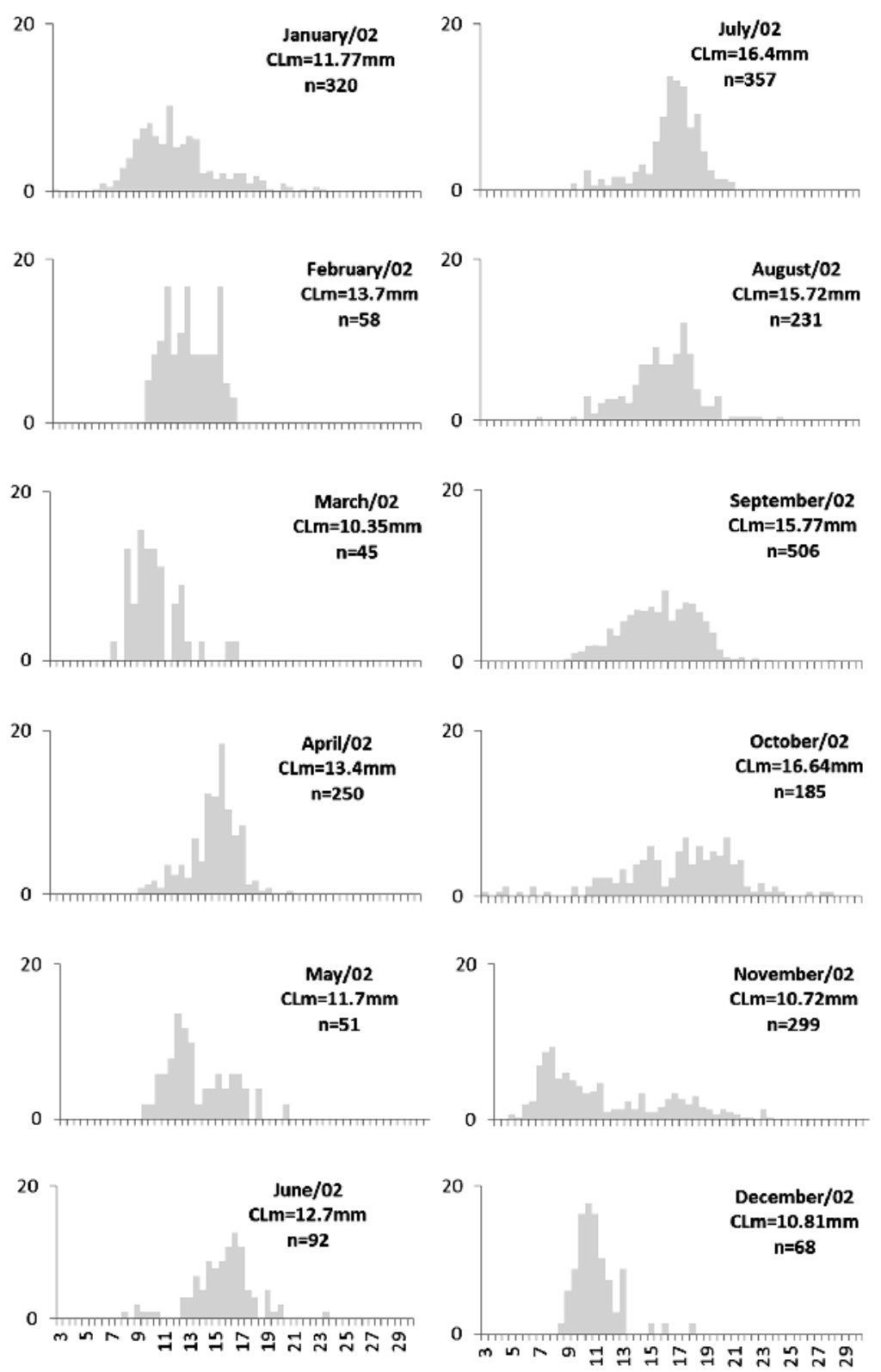

FIGURE 10 - Monthly variation in size structure (carapace length- $C L_{m m}$ ) of females, containing number of individuals measured (n) and mean carapace length $\left(\mathrm{CL}_{\mathrm{m}}\right)$. 
Analysis of $\mathrm{CL}$ data showed that differential length distribution of females occurred in studied area. Statistical comparison of mean length between isobaths $(5-15 \mathrm{~m}$ and $16-20 \mathrm{~m})$ suggests that significantly larger females $(p=0.0009)$ inhabited deeper grounds, in isobaths greater than 15 meters $(\mathrm{CL}=13.9 \pm 3.94 \mathrm{~mm})$. Conversely, smaller females $(\mathrm{CL}=9.89 \pm 3.71 \mathrm{~mm})$ presented a preference for shallower waters near the beach (Table II).

TABLE II - Trends in length (CLmm) composition grouped in two categories, from 5-15 and 16 to 20 meters. Summary of $t$ test results, including mean carapace length (CLmm), standard deviation of mean (std. dev.) and confidence intervals $(95 \%)$. Test showed significant differences between groups $(p=0.0009)$.

\begin{tabular}{rrrrrr}
\multicolumn{1}{c}{ depth } & \multicolumn{1}{c}{$\mathrm{n}$} & \multicolumn{1}{c}{ CLmm } & std. dev. & \multicolumn{2}{c}{ Cl (95\%) } \\
\hline overall & 1006 & 12.61 & 4.24 & 12.35 & 12.87 \\
$5-15$ & 328 & 9.89 & 3.95 & 9.46 & 10.32 \\
$16-20$ & 678 & 13.93 & 3.72 & 13.65 & 14.21 \\
\hline
\end{tabular}

The VBGM parameters, estimated by a least square procedure, are summarized in Figure 8. Longevity estimated by using inverted VBGM was 17.7 months and is in agreement with modal progression analysis. Asymptotic length $\left(\mathrm{LC}_{\infty}=\right.$ $29.6 \mathrm{~mm}$ ) estimated was close to largest size observed in the wild $(30.49 \mathrm{~mm})$ (Figure 11).

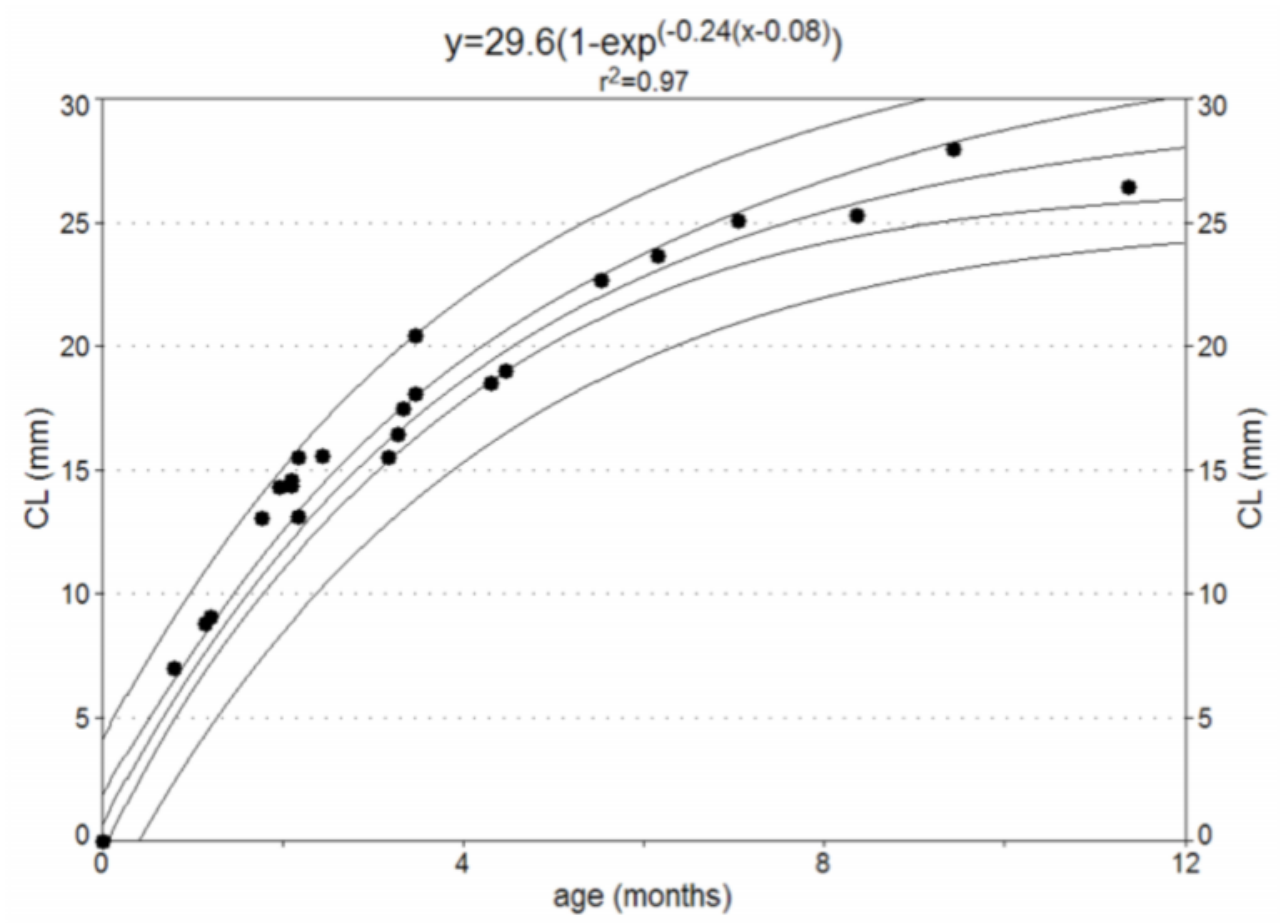

FIGURE 11 - Growth curve estimated for $A$. longinaris females by using the VBGM, containing the following growth parameters: asymptotic length $\left(\mathrm{CL}_{\infty}=29.6 \mathrm{~mm}\right)$, coefficient of growth $\left(\mathrm{k}=0.24 \mathrm{month}^{-1}\right)$ and age at zero length $\left(\mathrm{t}_{0}=-0.08 \mathrm{month}^{-1}\right)$.

Reproductive females observed during summer were likely hatched in previous spring and ranged from 4 to 6 months old. Autumn also presented a limited number of adult age classes (4 to 6 months old) as well as reduced frequency of ripe females and CPUE of adult females.
No recruitment peak was recorded during early winter months, despite of the presence of large (4 to 10 months old) and ripe females in the area. During late winter (September), a marked increase in recruitment density was observed, suggesting that spawning season starts during previous month with younger females. 
However, spawning reaches a maximum intensity in October when cohort hatched in previous spring reaches one year old. Late winter spawning is also confirmed by the presence of very small recruits in October, suggesting spawning activity during the previous month. Nevertheless, spring presented highest relative abundance of adult females, percentage of ovary maturation as well as larger females contributing to recruitment (4 to 12 months) (Figure 10). The importance of recruitment originated from October spawning is confirmed by high abundance of recruits during the following month (November), especially in class interval of $7 \mathrm{~mm}(\mathrm{CL})$ or the equivalent age of approximately 1 month (Figure 10).

In October, the highest $\mathrm{CL}$ mean value was verified, even with significant frequency of juveniles in length classes between 4 and 15 millimeters. The smaller $(C L=4 \mathrm{~mm})$ were probably hatched in October and the largest $(C L=15 \mathrm{~mm})$ in August. A marked decrease in mean CL was observed in November. This reduction in mean $\mathrm{CL}$ is explained by high frequency of small individuals (peak at $7 \mathrm{~mm}$ ), originated from October spawning (Figure 10).

\section{Stock-recruitment relationships (SRR) and multiple linear regression}

A total of 8699 female shrimps were used for stock-recruitment analysis. Two visually discrete adjusts were observed and data was separated in two main groups, the good and bad environmental conditions. This strategy was adopted to test significant influence of abiotic parameters on penaeid recruitment. Significant differences in mean salinity $(p=0.01)$ and rainfall $(p=0.04)$ during the spawning season between good (mean salinity $=28.9 \pm 3.3$ and total rainfall= $487 \pm 55 \mathrm{~mm}^{3}$ ) and bad years (mean salinity $=23.3 \pm 6.9$ and total rainfall $=577 \pm 14.88 \mathrm{~mm}^{3}$ ) were observed. Thus, these results provided the first insight on environmental factors influencing reproductive success of $A$. longinaris in Southern Brazil.

Among the three stock-recruitment models tested, only the Beverton \& Holt model showed significant fit under overall, bad and good environmental conditions. However, all three models presented significant fit for bad environmental conditions, suggesting that the spawning biomass is even more important when the environmental conditions are adverse (Table III).

TABLE III - Statistic summary of $A$. longinaris stock-recruitment data fitted to the models, containing the estimated parameters with standard deviations (within brackets) and coefficient of determination $\left(R^{2}\right)$. Significant adjusts are indicated by ${ }^{*}$ and non significant by ns. Overall p-values $(p(o v))$ are also provided. B\&H= Beverton and Holt model, $\mathrm{OV}=$ overall, $\mathrm{GE}=$ good environment and $\mathrm{BE}=$ bad environment.

\begin{tabular}{|c|c|c|c|c|c|}
\hline & $\mathbf{a}$ & b & K & $\mathbf{R}^{2}$ & $p(o v)$ \\
\hline Ricker (OV) & $16.1(6.37)^{\circ}$ & $0.01(0.004)^{\circ}$ & - & 0.44 & 0.03 \\
\hline Ricker (GE) & $19.9(8.13)^{\mathrm{ns}}$ & $0.01(0.004)^{\mathrm{ns}}$ & - & 0.54 & 0.15 \\
\hline Ricker (BE) & $10.4(2.31)^{x}$ & $0.01(0.003)^{*}$ & - & 0.95 & 0.01 \\
\hline $\mathrm{B} \& \mathrm{H}(\mathrm{OV})$ & $0.026(0.02)^{\mathrm{n} \mathrm{n}^{x}}$ & $0.002(0.0006)^{\pi}$ & - & 0.48 & 0.02 \\
\hline$B$ \& H (GE) & $0.005(0.002)^{\mathrm{ns}}$ & $0.002(0.00008)^{x}$ & - & 0.98 & 0.001 \\
\hline$B \& H(B E)$ & $0.07(0.03)^{*}$ & $0.003(0.0005)^{*}$ & - & 0.91 & 0.002 \\
\hline Shepherd (OV) & $7.99(16.9)^{\mathrm{ns}}$ & $0.97(5.7)^{\mathrm{ns}}$ & $74.3(933)^{\text {ns }}$ & 0.20 & 0.45 \\
\hline Shepherd (GE) & $19.99(40.1)^{\mathrm{ns}}$ & $0.93(3.0)^{\mathrm{ns}}$ & $33.2(353)^{\mathrm{ns}}$ & 0.30 & 0.41 \\
\hline Shepherd (BE) & $9.0(4.6)^{x}$ & $1.49(0.24)^{*}$ & $74.6(29.8)^{x}$ & 0.95 & 0.01 \\
\hline
\end{tabular}

Results obtained from overall multiple linear regression suggested that main factors influencing recruitment of $A$. longinaris in southern Brazil are salinity in spring $(\beta=0.96 ; p=0.05)$ and rainfall during recruitment $(\beta=-3.29 ; p=0.05)$, which indirectly results in lower salinity during recruitment. When the favorable environment years were analyzed separately, main factor affecting recruitment was salinity during spawning season $(\beta=0.99 ; p=0.00)$. During adverse environment years the main factor regulating recruitment biomass was the abundance of spawning stock $(\beta=1.01 ; p=0.03)$. Total amount of rain in spawning year was not included in the model, since no significant $p$-value was obtained. Table IV 
TABLE IV - Summary of multiple regression analysis estimated for A. longinaris in Southern Brazil. Three different models were obtained and significant $p$-values included are highlighted. SALS= salinity during spring (spawning season), RRC= rain during recruitment to commercial fishery, TRAIN= total rain during the spawning year and $\mathrm{SS}=$ spawning stock biomass.

\begin{tabular}{|c|c|c|c|c|c|c|c|}
\hline \multicolumn{8}{|c|}{ overall } \\
\hline & Beta & Std. Err. & $B$ & Std. Err. & $\mathrm{t}$ & $p$ & $\mathrm{R}_{\mathrm{ad}}^{2}$ \\
\hline SALS & 0.96 & 0.41 & 12.29 & 5.23 & 2.35 & 0.05 & 0.90 \\
\hline RRC & -3.29 & 1.41 & -1.25 & 0.53 & -2.34 & 0.05 & \\
\hline TRAIN & 3.15 & 1.69 & 0.75 & 0.40 & 1.87 & 0.10 & \\
\hline \multicolumn{8}{|c|}{ bad years } \\
\hline SS & 1.01 & 0.18 & 3.13 & 0.55 & 5.72 & 0.03 & 0.88 \\
\hline TRAIN & 0.24 & 0.18 & 0.12 & 0.08 & 1.39 & 0.30 & \\
\hline \multicolumn{8}{|c|}{ good years } \\
\hline SALS & 0.99 & 0.10 & 15.92 & 1.54 & 10.32 & 0.00 & 0.88 \\
\hline
\end{tabular}

\section{DISCUSSION}

\section{Seasonal reproductive dynamics and size at first maturity}

Artemesia longinaris clearly shows a year round spawning pattern, with main peak taking place in early spring (October). Preparation for main spawning event starts in winter, when increasing frequency of developing and ripe females were observed in surrounding area of Patos Lagoon Estuary. Furthermore, larger females, hatched during previous spring (12 months) participate in this reproductive event, which also increases the chances of successful recruitment (Vance et al. 1998).

Female penaeid shrimps usually present strong relationship between fecundity and size (Penn 1980). For instance, reared individuals of $A$. longinaris weighing $5 \mathrm{~g}$ produce more than 78000 eggs. Conversely, a female weighing $2 \mathrm{~g}$ produces only 1150 eggs (Scelzo 1991). Therefore, the presence of larger, as well as greater abundance of ripe females during October, explains the higher success of cohort hatched during spring.

Other two reproductive events, in autumn and in summer, are less important for population renewal and they seem to be more variable in intensity and period of occurence (Ruffino \& Castello 1992, Calazans 2002). Calazans (2002) reported autumn and spring as the seasons that concentrate similar high densities of $A$. longinaris post-larvae. Conversely, during the studied year, a much lower frequency and abundance of large and ripe females was recorded during autumn. Smaller females, hatched in summer and spring participated on this event, which was evidenced by size frequency and growth analysis. As stated by several authors (Gulland \& Rothschild 1981, Vance et al. 1998) penaeid shrimps inhabiting tropical and sub-tropical regions usually present two recruitment peaks, one in spring and a secondary in autumn, always connected to phytoplankton blooms. However, a marked interannual variation in strength, area and time of secondary reproductive events is very often observed in penaeid populations and it is usually explained by unfavorable environmental conditions (Vance et al. 1998).

It is important to stress out that during autumn/2002 and winter/2002, the Southern Brazilian coast was under the influence of El Niño Southern Oscillation (ENSO) (Wolten \& Timlin 1993, 1998), increasing rainfall and consequently reducing salt concentration in surrounding area of Patos Lagoon Estuary (Garcia et al. 1996). Dumont (2005), observed that $A$. longinaris tends to avoid lower salinity areas, under the influence of freshwater outflow from Patos Lagoon, which may have caused recruitment failure during this period.

The summer reproductive event is recognized as less important for population replenishing, since very low densities of post-larvae (Calazans 2002), adult and ripe females are reported. Females participating in this event are younger and originated from spring spawning (4 to 6 months) reaching final 
maturation during summer. Higher water temperature seems to have a negative effect on summer reproduction. Growth of $A$. longinaris reared at $26{ }^{\circ} \mathrm{C}$ is very low and mortality rate is high (89\%), suggesting that this temperature is close to lethal for this species (Haran et al. 1992). In summer, mean water temperature reached $25.64{ }^{\circ} \mathrm{C}$, approaching to lethal value reported for this species (Haran et al. 1992). Therefore, reproduction of $A$. longinaris in the coast of Rio Grande do Sul seems to be constrained during summer, since under relatively high temperatures larval production and survival of cohort hatched in this period is reduced (Haran et al. 1992).

Previous investigation performed in Argentinean coast concluded that reproductive activity is closely related to water temperature (Petriella \& Bridi 1992, Castillo et al. 2007). These investigations stress that ovary development is interrupted in autumn, synchronized with decreasing temperature. Spawning in Argentina is observed again only in December, when water temperature raeches $17^{\circ} \mathrm{C}$ (Petriella \& Bridi 1992). Therefore, population of $A$. longinaris inhabiting Southern Brazil presents an extended reproductive season, which is linked to the latitude and consequently the temperature regime of the region. Several penaeid shrimp species distributed in higher latitudes tend to present well defined reproductive seasons, constrained to few months (Dall et al. 1990), while those species that live in warmer latitudes tend to present ripe ovaries and spawning activity all year round (Gulland \& Rothschild 1981, Buckworth 1985, Crocos 1987). Briefly, reproductive cycle of $A$. longinaris coincides with pattern suggested to other penaeid shrimps, presenting a more stable spawning season in spring and secondary events more susceptible to environmental variation (Vance et al. 1998).

Besides the influence on the period of the reproductive cicle, temperature also plays an important role on size at first maturity, in such a way that populations distributed in higher latitudes have later gonadal development and therefore reach larger LM (Courtney \& Massel 1997). Comparison of mean length at first maturity of population inhabiting Southern Brazil $(16.76 \mathrm{~mm})$ to investigations performed in northern and southern limits of distribution confirms this pattern. The LM estimated for population inhabiting $23^{\circ} \mathrm{S}$ was $13.6 \mathrm{~mm}$, while the estimate for southern limit $\left(37^{\circ} 59^{\prime} \mathrm{S}\right)$ was $22.1 \mathrm{~mm}$ (Castillo et al. 2007). In fact, shrimp populations inhabiting higher latitudes tend to present slower growth rates and consequently delaying size at first maturity (Gulland \& Rothschild 1981).

Differential length composition by depth, suggests a reproductive migration of this species to deeper waters. Thus, it is likely that females move away from shallow waters to deeper fishing grounds (16-20m) to complete ovary maturation (Boschi 1969), avoiding areas under the influence of estuarine outflow (Dumont 2005). Spawning seems to occur in similar depths, since highest larval abundance was observed between 10 and 30 isobaths, decreasing from 30 to $60 \mathrm{~m}$ (Calazans 2002).

Migration of adult females to deeper waters was also observed in Argentina. During main reproductive season (summer) no mature females are found in artisanal fishing grounds (0-10 meters), suggesting a reproductive movement to deeper waters (Boschi 1969, Castillo et al. 2007). This pattern of reproductive migrations have been verified for several penaeid shrimps (Dall et al. 1990).

\section{Stock-recruitment and multiple regression analysis}

Stock-recruitment analysis (SRR) showed considerable interannual variations, which are not connected to any obvious trends in spawning stock biomass. It is quite clear that whatever the relationship between spawning stock and recruitment biomass, it is also influenced by environmental factors. Therefore, it is convenient to describe stock-recruitment relationship by a family of curves, each corresponding to an environment condition (Gulland \& Rothschild 1981). In the present paper we suggest the use of two different groups of SRR, one for favorable environmental conditions (good year), with higher recruit biomass ratio and another curve for lower recruitment ratio (bad year). Visual classification of spawning/recruit data was supported by significant differences in salinity during spawning season, in such a way that good years presented higher salinity and reduced rainfall. Salinity has been reported as the main factor influencing the recruitment success of penaeid shrimps (Garcia 1981) and it is especially 
true for penaeid species that cannot tolerate low salinities, where life cycle does not depend on an estuarine life stage (Anger 2003).

Changes in salinity can affect feeding activity as well as growth of crustaceans, altering metabolic pathways and developmental processes (Dall et al. 1990). This becomes especially conspicuous on yolk utilization during embryonic development, which may eventually cause significant intraspecific variation in the size and biomass of late eggs and early larvae (Giménez \& Anger 2001). Such mechanisms should therefore, affect viability and, in particular, the nutritional vulnerability of planktotrophic larvae, thus playing a significant role for chance of larval survival in species living under variable salinity regimes (Giménez 2002, Giménez \& Anger 2003).

Concern has been expressed that management decisions in the past had mostly been made on the basis that recruitment numbers are independent of parental stock abundance at levels of exploitations being experienced, in such a way that only environmental aspects regulate the recruitment success (Gulland \& Rothschild 1981). However, this statement may not hold true for all shrimp fisheries (D'Incao et al. 2002), since high exploitation rates combined with unfavorable environmental conditions can cause dangerous reductions in spawning biomass. This is clearly true for $A$. longinaris, since highly significant fits to SRR models were observed under bad environmental conditions.

The Beverton \& Holt model showed the best fit to spawning and recruitment biomass and as previously stated describes a relationship where an asymptotic density of spawning biomass is achieved, stabilized by density-dependent factors. The best fit of Beverton \& Holt model to shrimp data was also observed in other shrimp fisheries worldwide (e.g. Cheng 1981), agreeing with results obtained in this investigation. Despite of problems reported for stock-recruitment relationships, this model can be used to detect recruitment overfishing, especially under very low spawning biomass levels, as well as to understand the resilience of studied population (Maury 1996).

The preliminary predictive model developed permits to conclude that salinity at spawning season and rain at recruitment explain $90 \%$ of recruitment success of $A$. longinaris in surrounding area of Patos
Lagoon when all years are pooled together. Salinity is widely known as a limiting factor for penaeid shrimp reproduction and most of species depend on higher salinity to maturate the ovaries (Dall et al. 1990). The amount of rainfall during recruitment season is clearly linked to reductions in salinity of studied area (Garcia 1996), resulting in a negative effect on cohort survival. Since in this group, most metabolic and physiological processes (e.g. reproduction) require a stable osmotic and ionic environment, salinity is generally considered a key ecological factor in coastal and estuarine areas (Anger 2003).

The negative effect of brackish water on stenohaline coastal species, such as $A$. longinaris, is that under suboptimal salinity concentration the energetic requirements are increased due to hyperosmoregulation (Kinne 1971). Allocation of the energy initially designated to reproduction is diverted to osmotic regulation and may inhibit ovary maturation of shrimps, since it is a high energy demanding process (Dall et al. 1990).

Suboptimal salinities also play a negative role on decapod crustacean larvae. Brackish water can slow down the molt interval and reduce growth, delaying larval development (Anger 2003). Even a slight delay in larval development may further reduce the chance of survival in plankton where slowly developing larvae are exposed for longer period to potentially harmful factors, such as physical stress, food limitation and pelagic predation (Lalli \& Parsons 2006).

Results obtained from bad year regression reinforce those estimated through SRR. As previously mentioned, dangerous spawning biomass levels can be achieved under unfavorable environmental conditions, and preservation of biomass during these periods is vital to keep the stock healthy. Conversely, salinity is the main factor during those years considered as favorable. Even under low spawning biomass, the high fecundity (Scelzo 1991), growth rate (Ruffino \& Castello 1992) and continuous spawning along the year allow recruitment success for this species.

Results obtained from multiple regressions must be carefully interpreted and only provide a preliminary idea about main factors affecting SRR, since a few number of seasons were analyzed. Therefore, further investigation must be developed using more variables and a greater number of years to identify new 
environmental factors causing trends in stock biomass. Nevertheless, results obtained in this investigation confirm salinity as key factor for reproductive success of $A$. longinaris in surrounding area of Patos Lagoon. Once reproductive seasons analyzed in present investigation showed marked differences in terms of importance to population replenishing, future analysis can be refined assuming heterogenic reproductive performances along the year and differential depth distribution according to size. The evident susceptibility to environmental factors and high natural mortality rates (Ruffino \& Castello 1992) combined with excessive fishing effort may cause serious harm to the stock of $A$. longinaris in southern Brazil.

\section{ACKNOWLEDGEMENTS}

Authors thank to Secretaria de Ciência e Tecnologia do Estado do Rio Grande do Sul (FAPERGS) for providing financial support to project Camarões Oceânicos and to Coordenação de Aperfeiçoamento de Pessoal de Nível Superior (CAPES) for studentship provided. We would also like to thank Universidade Federal de Pelotas (UFPEL) for providing the rainfall data used in this paper.

\section{REFERENCES}

ANGER, K. 2003. Salinity as a key parameter in the larval biology of decapod crustaceans. Inv. Reproduction and Development, 43(1), 29-45.

ASMUS, ML. 1996. Coastal plain and Patos Lagoon. In: Subtropical convergence environments, the coast and sea in the Southwestern Atlantic, U. Seeliger, C. Odebrecht \& J.P. Castello (eds.), Springer, Berlin, pp. 9-12.

BERTALANFFY, L VON 1938. A quantitative theory of organic growth (Inquites on growth laws II). Human Biology, 10(2):181-213.

$\mathrm{BOSCHI}$, EE. 1969. Estudio biológico pesquero del camarón Artemesia longinaris Bate, 1888 de Mar del Plata. Boletin del Instituto de Biologia Marina, 18: 1-47.

BUCKWORTH, RC. 1985. Preliminary results of a study of commercial catches, spawning and recruitment of Penaeus esculentus and Penaeus semisulcatus. In: Second Australian Shrimp Seminar, P.C. Rothlisberg, B.J. Hill \& D.J. Staples (eds.), pp. 85-93.

CALAZANS, D. 2002. Seasonal larval composition and abundance of shrimps in the surrounding area of the Patos Lagoon mouth. Nauplius, 10(2): 111-120.

CASTILLO, AL, MA GAVIO, RC COSTA, EE BOSCHI, RT BAUER \& A FRANSOZO. 2007. Latitudinal variation of poulation structure and reproductive pattern of the endemic south american Artemesia longinaris (DECAPODA:PENAEOIDEA). Journal of Crustacean Biology, 27(4): 548-552.

CHA, HK, C OH, SY HONG \& KY PARK. 2002. Reproduction and population dynamics of Penaeus chinensis (Decapoda:Penaeidae) on the western coast of Korea, Yellow
Sea. Fisheries Research, 56: 25-36.

CHENG, YC. 1981. The shrimp (Penaeus orientalis Kishinouye) in Pohai Sea and their fishery. In: Second Australian Shrimp Seminar, P.C. Rothlisberg, B.J. Hill \& D.J. Staples (eds.), pp. 49-60.

CHRISTIANSEN, HE \& MA SCELZO. 1971. Ciclo de maduración sexual y observaciones sobre la morfología del aparato genital del camarón Artemesia longinaris Bate, 1888. Carpas, 16(5/D): 1-22.

CIOTTI, AM, C ODEBRECHT, G FILLMAN \& OOJr MOLLER. 1995. Freshwater outflow and Subtropical Convergence influence on phytoplankton biomass in southern Brazilian coastal shelf. Continental Shelf Research, 15(14): 1737-1756.

COSTA, RC, A FRANSOZO, AL CASTILHO \& FAM FREIRE. 2005. Annual, seasonal and spatial variation of the shrimp Artemesia longinaris (Decapoda: Penaeoidea) in south-eastern Brazil. Journal of Marine Biology Association of United Kingdom, 85: 107-112.

COURTNEY, AJ \& JM MASSEL. 1997. Spawning stock dynamics of two penaeid shrimps, Metapenaeus bennettae and Penaeus esculentus, in Moreton Bay, Queensland, Australia. Marine Ecology Progress Series, 148: 37-47.

CROCOS, PJ. 1987. Reproductive dynamics of the tiger shrimp Penaeus esculentus, and a comparison with $P$. semisulcatus, in the north-western Gulf of Carpentaria, Australia. Aust. Journal of Freshwater Research, 38: 91-102.

CROCOS, PJ, YC PARK, DJ DIE, K WARBURTON \& F MANSON. 2001. "Reproductive dynamics of endeavour prawns, Metapenaeus endeavouri and M-ensis, in Albatross Bay, Gulf of Carpentaria, Australia." Marine Biology 138(1): 63-75.

DALL, W, BJ HILL, PC ROTHLISBERG \& DJ STAPLES. 1990. The biology of the penaeidae. Advances in Marine Biology, 27: 1-489.

D'INCAO, F \& DB FONSECA. 2000. Performance of the von Bertalanffy growth curve in penaeid shrimps: A critical approach. In: The biodiversity crisis and Crustacea: Proceedings of the Fourth International Crustacean Congress, J.C. von Vaupel Klein, \& F.R. Schram (eds.), Amsterdam, pp 733-737.

D'INCAO, F, H VALENTINI, \& LF RODRIGUES. 2002. Avaliação da pesca de camarões nas regiões Sudeste e Sul do Brasil. 1965-1999. Atlântica, 24(2): 49-62.

DUMONT, LFC \& F D‘INCAO. 2004. Estágios de desenvolvimento gonadal de fêmeas do camarão-barba-ruça (Artemesia longinaris - Decapoda: Penaeidae). Iheringia, 94(4): 389-393.

DUMONT, LFC. 2005. Distribuição de abundância do camarãobarba-ruça (Artemesia longinaris) e do camarão-santana (Pleoticus muelleri) no litoral do Rio Grande do Sul. In: Ações para Conservação de Tubarões e Raias no Sul do Brasil, C.M. Vooren \& S. Kliepel (eds.), Instituto Igaré, Porto Alegre, pp. 129-134.

FAO - 2007. The world state of fisheries and aquaculture - 2006. FAO Fisheries and Aquaculture Department, Rome, 180p.

FRISCH, AJ. 2007. Growth and reproduction of painted spiny lobster (Panulirus versicolor) on the Great Barrier Reef (Australia). Fisheries Research, 85: 61-67.

GARCIA, S. 1981. Environment aspects of penaeid shrimp biology and dynamics. In: Penaeid shrimps: their biology and management, J.A. Gulland \& B.J. Rotschild (eds.), Fishing news books, England, pp. 268-271.

GARCIA, S. \& L LE RESTE. 1981. Life cycles, dynamics, exploitation and management of coastal penaeid shrimp stocks. FAO Fisheries Technical Paper, Rome, 203, 215p.

GARCIA, CAE. 1996. Hydrographic characteristics. In: Subtropical 
convergence environments, the coast and sea in the Southwestern Atlantic, U. Seeliger, C. Odebrecht \& J.P. Castello (eds.), Springer, Berlin, pp. 18-20.

GARCIA, AA JP VIERIA, CE BEMVENUTI \& RM GERALDI. 1996. Abundância e diversidade de crustáceos decápodos dentro e for a de uma pradaria de Ruppia maritime L. no estuário da Lagoa dos Patos (RS-Brasil). Revista Nauplius (Rio Grande) 4: 113-128.

GAYANILO, JFC, P SPARRE \& D PAULY. 1995. The FAOICLARM Stock Assessment Tools (FISAT). FAO, Rome, 186p.

GIMÉNEZ, L \& K ANGER. 2001. Relationships among salinity, egg size, embryonic development and larval biomass in the estuarine crab Chasmagnatus granulata Dana, 1851. Journal of Experimental Marine Biology and Ecology, 260: 241-257.

GIMÉNEZ, L. 2002. Effects of prehatching salinity and initial larval biomass on survival and duration of development in zoea 1 of the estuarine crab Chasmagnathus granulata under nutritional stress. Journal of Experimental Marine Biology and Ecology, 270: 93-110.

GIMÉNEZ, L \& K ANGER. 2003. Larval performance in estuarine crab Chasmagnathus granulata is a consequence of both larval and embryonic experience. Marine Ecology Progress Series, 249: 251-264

GULLAND, JA \& BJ ROTSCHILD. 1981. Penaeid shrimps: their biology and management. Fishing news books, 299p.

HARAN, NS, JL FENUCCI \& AC DIAZ. 1992. Efectos de la temperatura y la salinidad sobre el crecimiento y la supervivencia del camarón (Artemesia longinaris) y del langostino (Pleoticus muelleri). Frente Maritimo, 11: 79-84.

KING, MG. 1997. Fisheries biology, assesment and management. Fishing News Books, England, 341p.

KINNE, O. 1971. Salinity. In: Marine Ecolgy. A comprehensive, Integrated Treatise on Life in Oceans and Coastal Waters, $\mathrm{O}$. Kinne (ed.), vol. 1, Wiley, London pp. 683-1244.

KIRKWOOD, GP. 1981. Modelling of the Gulf of Carpentaria shrimp fisheries. In: Penaeid shrimps: their biology and management, J.A. Gulland \& B.J. Rotschild (eds.), Fishing news books, England, pp. 211-219.

LALLI, CM \& TR PARSONS. 2006. Biological Oceanography: an introduction. Elsevier, Osford, 314p.

LÓPEZ-MARTÍNEZ, J, C RÁBAGO-QUIROZ, MO NEVÁREZMARTÍNEZ, AR GARCÍA-JUARÉZ, G RIVERA-PARRA \& J CHÁVEZ-VILLALBA. 2005. Growth, reproduction and size at first maturity of blue shrimp Litopenaeus stylirostris (Stimpson, 1874) along the coast of the Gulf of California, Mexico. Fisheries Research, 71: 93-102.

MAURY, O. 1996. A generalized stock-recruitment relationship fitted to the observed yield: implications for the recruitment dynamic. Aquatic Living Resources, 9: 291-304.
NASCIMENTO, PAM. 1981. Variações no tamanho médio de maturação em Artemesia longinaris Bate, 1888 (Crustacea, Decapoda, Penaeidae). Naturalia, 6: 33-42.

PAULY, D. 1987. A review of the ELEFAN system for the analysis of length-frequency data in fish and aquatic invertebrates. In: Length-Based Methods in Fishery Research, D. Pauly \& G.R. Morgan (eds.), ICLARM Conference Proceedings, pp. 7-34.

PAULY, D. 1992. A method to estimate the stock-recruitment relationship of shrimps. Transactions of the American Fishery Society, 111(1): 13-20.

PENN, JW. 1980. Spawning and fecundity of the western king shrimp, Penaeus latisulcatus in Western Australian waters. Australian Journal of Freshwater Research, 31: 21-35.

PETRIELLA, AM \& RJ BRIDI. 1992. Variaciones estacionales del ciclo de muda y la maduración ovárica del camarón (Artemesia longinaris). Frente Maritimo, 11: 85-92.

PIOLA, AR, OOJr MOLLER \& ED PALMA. 2004. El impacto del Plata sobre el oceano Atlántico. Ciencia Hoy, 14(2) 20-37.

PIOLA, AR, RP MATANO, ED PALMA, OOJr MOLLER \& EJD CAMPOS. 2005. The influence of the Plata River discharge on western South Atlantic shelf. Geophysical Research Letters, 32: 1-4.

RUFFINO, ML \& JP CASTELLO. 1992. Dinámica poblacional del camaron (Artemesia longinaris) del sur de Brasil. Frente Maritimo, 12(A): 71-81.

SCELZO, MA. 1991. Copula en cautiverio y desove del camaron Artemesia longinaris Bate, 1888 (Decapoda, Penaeidae). Informes Tecnicosc de Ciencia Marina, 164: 1-16.

STAPLES, DJ, DJ VANCE \& DS HEALES. 1985. Habitat requirements of juvenile penaeid prawns and their relationship to offshore fisheries. In: Second Australian National Prawn Seminar. pp.47-54. Ed. by P. Rothlisberg, B. Hill and D. Staples. NPS2, Cleveland, Qld. 368 pp.

UNIVALI 2011. Boletim estatístico da pesca industrial de Santa Catarina - Ano - 2010. Itajaí, outubro de 2011, 56p.

VANCE, DJ, MDE HAYWOOD, DS HEALES, RA KENYON \& NR LONERAGAN. 1998. Seasonal and annual variation in abundance of postlarval and juvenile banana shrimps Penaeus merguiensis and environmental variation in two estuaries in tropical northeastern Australia: a six year study. Marine Ecolology Progress Series, 163: 21-36.

WOLTER, K, \& MS TIMLIN. 1993: Monitoring ENSO in COADS with a seasonally adjusted principal component index. Proceedings of the 17th Climate Diagnostics Workshop, Norman, OK, NOAA/N MC/CAC, NSSL, Oklahoma Clim. Survey, CIMMS and the School of Meteorology, University of Oklahoma, 52-57.

WOLTER, K \& MS TIMLIN. 1998: Measuring the strength of ENSO events - how does 1997/98 rank? Weather, 53: 315-324.

Submetido: $15 / 07 / 2010$

Aceito: 07/12/2011 
